\title{
HOW TRUST AND QUALITY OF INFORMATION AFFECT BUYING INTEREST AND PURCHASING DECISIONS? (study on Shopee customers in Samarinda)
}

\author{
Mochamad Ridwan ${ }^{1)}$ Theresia Militina $^{2)}$ Gusti Noorlitaria Achmad ${ }^{3)}$ \\ Master of Management Faculty of Economics and Business, University of Mulawarman \\ E-mail:mochamadridwan10@gmail.com
}

\begin{abstract}
This study aims to determine the effect of confidence (trust) and Quality Information and Decision on Interest Buy Pebelian (Studies in Samarinda Shopee customers). Online shopping how to use the Internet through computers and mobile devices is increasingly popular smartphone can even be said to have become the trend of today. The population in this study is the customer who Shopee samarinda use application Shopee in transacting online, The samples in this study as many as 150 respondents. Methods Data collection is done by providing a list of questions or questionnaires to respondents that the study sample, where questionnaires were distributed through WhatApp application. This study uses data analysis tools is to test the validity and reliability test, then this research analysis method of partial least square (PLS). The tools used in processing the data using PLS Smart program. Research results show that 1) Belief positive and significant impact on the buying interest of customers Shopee Samarinda, 2) trust has a positive effect but not significant to purchasing decisions of customers Shopee Samarinda, 3) Quality of information about positive and significant effect on the buying interest of customers Shopee Samarinda, 4) Quality of information about positive and significant effect to the purchasing decision of customers Shopee Samarinda, 5) buying interest and significant positive effect on customer purchasing decisions Shopee Samarinda,
\end{abstract}

Keywords:Trust, Quality Information, Interests Buy, Purchase Decision

\section{Introduction}

Electronic Business with Online Shopping concept prevalent in recent years along with the development of communication technologies over the Internet. Trading activities is a routine activity that occurs on a daily basis. Trading activities will be implemented if there is an agreement between two parties to exchange goods and services with money. With the increasingly rapid development of technology, the means to undertake trading activities was growing. Trading activities no longer require sellers and buyers meet. Purchases or transactions can be done at home, easily, simply by using the internet, accompanied by corresponding with money, consumers are able to buy whatever they need.

Trust is an important aspect in a good deal online and offline. According to(Kotler \& Armstrong, 2018; 187)trust as an initial step how a consumer will initiate the transaction, the stronger the bond of trust (trust) that is built between a seller and a buyer, the more likely a buyer will repeat the transaction. The indicator or measure of the variable Trust (the Trust) (X1) was adopted from previous studies in research(Pavlou and Gefen, 2003) expressed confidence indicators are divided into three, namely: Caring, Reliability seller, and Credibility. 
Quality is quality information relating to the number, accuracy and the form of information about products and services offered on the website (Alhasanah \& al, 2014), Meanwhile, according to(Abdulrahman \& Mohammed, 2017)stated that most consumers choose Online market in the deal is, access opportunities every time, ease of transactions without going through the queue in the purchase, many variations of the products supplied and accompanied by a variety of price offered, the ease of comparing prices before buying, as well as many reviews from consumers others who have bought goods on the site. The indicator or measure of the variable Quality Information (Information Quality) adopted from previous studies byLoo (2011) As for the indicators of the variable quality of information, namely: information is accurate, up to date information, time information, and the information is clear.

According to (Schiffman \& Kanuk 2010: 201)suggests that the interest is one of the psychological aspects that possess considerable influence on behavior attitude. Buying interest can be interpreted as a happy attitude toward an object that makes an individual attempting to get the object by paying with cash or sacrifice. The indicator or measure of the variable interest Buy adopted from previous research indicators contained in the Interests Buy among others: interest (interest), desire (desire), conviction (conviction), and transactional Interests,

Decision purchases made by customers online and offline quite have a striking difference. One difference is shopping device used and the way marketing is quite different between online and offline. According to(Penia et al, 2016)Online purchasing decisions in the network is the process of consumer purchases made through alternative processes using internet media having value higher. In this study, the indicators used are the indicators adopted from(Kotler \& Keller, 2015) and (Majid, 2014) consisting of: Set the option to the product,Confidence to buy, Purchase Frequency, and Overall Satisfaction.

\section{Research Method}

This research was a survey, in which the data collection using questionnaires. The survey is research taking sample from a population and as the principal means of collecting data. Understanding restricted to the survey sample survey in which part of the population is taken to represent the entire study. In this study population wasfemale and male consumers who ever bought and use applications Shopee in the city of Samarinda. Total population of the exact figure is not known.

Techniques used in the sampling in this research is to use the Snowball Sampling. Snowball sampling is a sampling technique that initially a small amount, and then enlarge. Like a snowball rolling that long to be great,(Sugiyono, 2009), In the sampling, first of all been one or two people, but because the two men do not feel complete on the data given, the researchers are looking for other people who are seen as more know and can complete the data provided by the previous two. So on so the sample size is growing. Determination of the number of samples of populai which cannot be known with certainty the amount obtained from the formula(Hair et al, 2014) that the number of samples used at least 100-200 sample and is calculated by multiplying the number of indicators with a scale of 5 to 10 . In this study, there were 15 indicators of research and using the multiplier is 10 , so the number of his research samples are as follows:

Number of samples $\quad=15 \times 10=150$ samples $/$ respondents 
International Journal of Economics, Business and Accounting Research (IJEBAR)

Peer Reviewed - International Journal

Vol-4, Issue-1, 2020 (IJEBAR)

E-ISSN: 2614-1280 P-ISSN 2622-4771

https://jurnal.stie-aas.ac.id/index.php/IJEBAR

The variables were observed in this study were four variables consisting of two exogenous and endogenous 2 with 15 indicators, then with reference to the calculation of the minimum number of samples, the number of samples selected for this study was 150 respondents.

\section{Results and Discussion}

\subsection{Results}

Based on the answers given by the respondents in this study, it can be explained several criteria reseponden ie gender, age, and income respondents.

Table 3.1

Gender

\begin{tabular}{|c|c|c|c|}
\hline No. & Gender & amount & Percentage \\
\hline 1. & Male & 53 & $35.3 \%$ \\
\hline 2. & woman & 97 & $64.7 \%$ \\
\hline \multicolumn{2}{|c|}{ Total } & 150 & $100 \%$ \\
\hline
\end{tabular}

Source: Calculated by the author, 2019

In table 3.1 above, shows that out of 150 respondents, the number of respondents who are predominantly women respondents were 97 respondents.

Table 3.2

Data Respondents by Age

\begin{tabular}{|c|c|c|c|}
\hline No. & Age (Years) & amount & Percentage \\
\hline 1. & $17-20$ & 37 & $24.7 \%$ \\
\hline 2. & $21-30$ & 91 & $60.7 \%$ \\
\hline 3. & $31-40$ & 13 & $8.7 \%$ \\
\hline 4. & $41-50$ & 9 & $6.0 \%$ \\
\hline \multicolumn{2}{|r|}{ amount } & 150 & $100 \%$ \\
\hline
\end{tabular}

Source: Calculated by the author, 2019

In table 3.2 above, shows that out of 150 respondents, the number of respondents is the dominant respondents aged 21 to 30 years that as many as 91 respondents.

Table 3.3

Data Respondents by revenue.

\begin{tabular}{|c|c|c|}
\hline Income & amount & Percentage \\
\hline <IDR. 1,000,000 & 51 & $34.0 \%$ \\
\hline Rp. 1,000,000 - Rp. 2000.000 & 36 & $24.0 \%$ \\
\hline Rp. 2,000,000 - Rp. 3,000,000 & 33 & $22.0 \%$ \\
\hline > Rp. 3,000,000 & 30 & $20.0 \%$ \\
\hline Total & 150 & $100 \%$ \\
\hline
\end{tabular}

Sources: Primary data is processed in 2019 
International Journal of Economics, Business and Accounting Research (IJEBAR)

Peer Reviewed - International Journal

Vol-4, Issue-1, 2020 (IJEBAR)

E-ISSN: 2614-1280 P-ISSN 2622-4771

https://jurnal.stie-aas.ac.id/index.php/IJEBAR

In table 3.3 above, shows that out of 150 respondents, the number of respondents is the dominant respondents with incomes <Rp.1.000.000 by 51 respondents.

\subsection{Discussion}

Validity and reliability are used to test the instrument in the form of indicators and questions to be eligible or can be used as a measurement variable. Validity and reliability tests conducted on 30 respondents in advance as a test that can be seen in the following table:

Table 3.4

Validity of Test Results

\begin{tabular}{|l|l|l|l|l|}
\hline variables & Indicator & $\begin{array}{l}\text { Pearson } \\
\text { Correlation }\end{array}$ & limit Values & Information \\
\hline Trust (Trust)(X1) & $\mathrm{X} 1.1$ & 0,751 & 0.3 & valid \\
& $\mathrm{X} 1.2$ & 0.767 & 0.3 & valid \\
& $\mathrm{X} 1.3$ & 0.815 & 0.3 & valid \\
\hline Quality Information & $\mathrm{X} 2.1$ & .808 & 0.3 & valid \\
(X2) & $\mathrm{X} 2.2$ & 0.823 & 0.3 & valid \\
& $\mathrm{X} 2.3$ & 0,836 & 0.3 & valid \\
& $\mathrm{X} 2.4$ & .837 & 0.3 & valid \\
\hline interests Buy & $\mathrm{Y} 1.1$ & .902 & 0.3 & valid \\
(Y1) & $\mathrm{Y} 1.2$ & .881 & 0.3 & valid \\
& $\mathrm{Y} 1.3$ & .840 & 0.3 & valid \\
& $\mathrm{Y} 1.4$ & .923 & 0.3 & valid \\
\hline Buying decision & $\mathrm{Y} 2.1$ & 0846 & 0.3 & valid \\
(Y2) & Y2.2 & 0861 & 0.3 & valid \\
& Y2.3 & 0746 & 0.3 & valid \\
& $\mathrm{Y} 2.4$ & 0.779 & 0.3 & valid \\
\hline
\end{tabular}

Sources: Primary data were processed using SPSS, 2019

Based on Table 5.1 above, indicate that the validity of the test results for a sample of 30 respondents showed, respectively - each Pearson Correlation value of each indicator (20 grains questions) is greater than the value of the limit value of 0.3 (the value of Pearson Correlation> Limit Value). It can be concluded that all the indicators used in this study is valid (legitimate) to measure the research variables.

Reliability test used to determine whether a reliable indicator used as a measurement variable. Reliability test results are as follows:

Table 3.5

Test results reliability

\begin{tabular}{|l|l|l|l|}
\hline variables & $\begin{array}{l}\text { Cronbach's } \\
\text { Alpha }\end{array}$ & limit Values & Information \\
\hline $\begin{array}{l}\text { Trust (Trust) } \\
\text { (X1) }\end{array}$ & 0666 & 0.60 & reliable \\
\hline $\begin{array}{l}\text { Quality } \\
\text { Information }\end{array}$ & 0844 & 0.60 & reliable \\
\hline
\end{tabular}


International Journal of Economics, Business and Accounting Research (IJEBAR)

Peer Reviewed - International Journal

Vol-4, Issue-1, 2020 (IJEBAR)

E-ISSN: 2614-1280 P-ISSN 2622-4771

https://jurnal.stie-aas.ac.id/index.php/IJEBAR

\begin{tabular}{|l|l|l|l|}
\hline$(\mathrm{X} 2)$ & & & \\
\hline $\begin{array}{l}\text { interests Buy } \\
(\mathrm{Y} 1)\end{array}$ & 0906 & 0.60 & reliable \\
\hline $\begin{array}{l}\text { Buying decision } \\
(\mathrm{Y} 2)\end{array}$ & 0819 & 0.60 & reliable \\
\hline
\end{tabular}

Sources: Primary data were processed using SPSS, 2019

Based on Table 5.2, shows that for a sample of 30 respondents reliability testing done by one shot, ie when the value of the variable Cronbach's alpha> 0.60 then the indicators used by the variable is reliable, while the Cronbach's alpha value of a variable $<0.60$ the indicators used by the variable is not reliable.

Based on the calculations, Cronbach's alpha value for each of the questions have been qualified reliability, the Cronbach's alpha value for each item the question has exceeded the minimum requirement level of reliability or Cronbach's alpha> 0.60 . It shows that from the point questions all reliable or would produce the same value, if there is twice or more.

\section{Examination Goodness of Fit Models}

Knowing goodness-fit models can be seen from the value of R-Square. R-square value can be used to explain the influence of independent variable on the dependent variable has a substantive effect.

Table 3.6

R - Square

\begin{tabular}{|l|c|c|c|}
\hline No. & Variables & R Square & R Square Adjusted \\
\hline 1. & Interest Buy & 0.755 & 0.756 \\
\hline 2. & Buying Decision & 0.617 & .609 \\
\hline
\end{tabular}

Source: Adapted Writers, 2019

Based on the table it can be seen that the buying interest has the R-square value of 0.755 which means that customer satisfaction can be explained by the Trust (the Trust) and Quality Information was $75,5 \%$. While the other $24.5 \%$ is explained by other variables outside studied. Furthermore Decisions to buy have R-square value of 0.617 which means the purchase decision can be explained by the Trust (the Trust) and the Information Quality of 65.7\%. While the other $34.3 \%$ is explained by other variables outside studied.

Structural models or Inner Model

Figure 3.1

Results bootstrapping

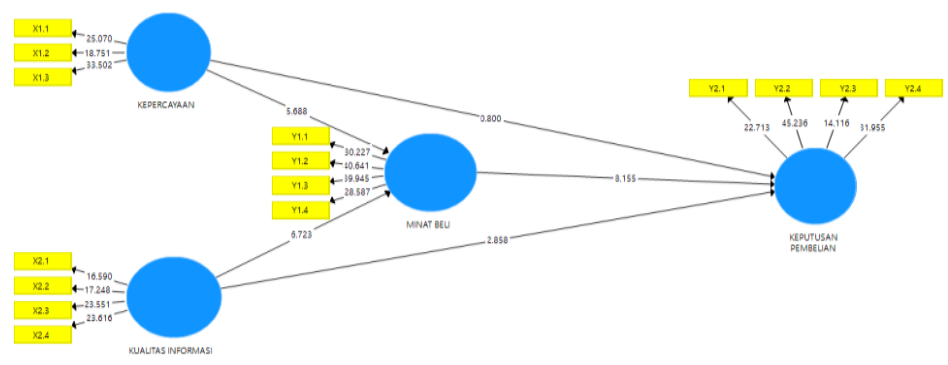

International Journal of Economics, Business and Accounting Research (IJEBAR) 
International Journal of Economics, Business and Accounting Research (IJEBAR)

Peer Reviewed - International Journal

Vol-4, Issue-1, 2020 (IJEBAR)

E-ISSN: 2614-1280 P-ISSN 2622-4771

https://jurnal.stie-aas.ac.id/index.php/IJEBAR

In testing the application program smart PLS t-test on each track. The test results can be seen in Table 5:13 below:

table 3.7

path Coefficients

\begin{tabular}{|l|r|r|r|r|r|}
\hline & $\begin{array}{l}\text { Original } \\
\text { Sample }\end{array}$ & $\begin{array}{l}\text { sample } \\
\text { Mean }\end{array}$ & $\begin{array}{l}\text { Standard } \\
\text { Deviation }\end{array}$ & \multicolumn{1}{c|}{ T-Statistics } & P Values \\
\hline Trust $\rightarrow$ Interests Buy & 0394 & 0394 & 0069 & 5,688 & 0000 \\
\hline $\begin{array}{l}\text { Belief } \rightarrow \text { Purchasing } \\
\text { Decisions }\end{array}$ & 0076 & 0076 & 0095 & 0800 & 0425 \\
\hline $\begin{array}{l}\text { Quality Information } \rightarrow \\
\text { Interests Buy }\end{array}$ & 0439 & 0439 & 0065 & 6723 & 0000 \\
\hline $\begin{array}{l}\rightarrow \text { Information Quality } \\
\text { Purchasing Decisions }\end{array}$ & 0212 & 0202 & 0074 & 2,858 & 0005 \\
\hline $\begin{array}{l}\text { interests Buy } \rightarrow \\
\text { Buying decision }\end{array}$ & 0568 & 0578 & 0070 & 8155 & 0000 \\
\hline
\end{tabular}

Sources: Primary data are processed, 2019

With hypotheses that have been formulated in the previous chapter, the results of hypothesis testing of table 3.7 can be summarized as follows:

H1 : Stating that the better the Trust (the Trust) positive and significant impact will be even better Interests Buy. Hypothesis Testing Results T-statistics value of 5.688> 1.96, which means that the hypothesis that positive and significant impact on customer satisfaction proved to be true or $\mathrm{H} 1$ accepted.

H2 : Stating that the better the Trust (the Trust) positive and significant impact, the higher the purchase decision. Based on the results of hypothesis testing known that the Trust (the Trust) have a positive influence but does not significantly influence purchase decisions with T-statistics value of $0,800<1.96$. So this result is not in accordance with the second hypothesis which states Trust (the Trust) is positive but not significant influence on the purchase decision or hypothesis 2 is rejected.

H3 : Stating that the better the quality of information is a positive and significant effect on the higher interest Buy. Based on the results of hypothesis testing is known that the quality of information provide a positive and significant effect on the interest Buy the T-statistics value of 6.723>1.96. So the results of this study in accordance with the third hypothesis stating Information Quality positive and significant impact on the Interests Buy. Hypothesis 3 is accepted.

H4 : Stating that the better the quality of information is a significant and positive effect will be higher purchase decision. Based on the results of hypothesis testing is known that the quality of information provide a positive and significant influence on the purchase decision with T-statistics value by $2,858>1.96$. So the results of this study in accordance with the fourth hypothesis stating Information Quality significant effect on purchase decision proved to be correct or accepted hypothesis 4.

H5 : Stating that the higher interest to Buy a positive and significant effect on the higher purchase decision. Based on the results of testing the hypothesis in mind that interest Buy provides a positive and significant influence on the purchase decision with T-statistics value of 8.155> 1.96. So the results of this study in accordance with the fifth hypothesis which states Interests Buy significantly influence the purchase decision proved to be correct or acceptable hypothesis 5 . 
International Journal of Economics, Business and Accounting Research (IJEBAR)

Peer Reviewed - International Journal

Vol-4, Issue-1, 2020 (IJEBAR)

E-ISSN: 2614-1280 P-ISSN 2622-4771

https://jurnal.stie-aas.ac.id/index.php/IJEBAR

\section{Conclusion and Suggestion}

Conclusion

Based on the analysis and discussion, can be concluded as follows.

1. Belief positive and significant impact on customer buying interest Shopee. These results indicate increased level of confidence whether or not someone will create a need to shop online at Shopee

2. Confidence but not significant positive effect on customer purchasing decisions shopee. These results show the Trust (the Trust) customers increased or not, it will not influence purchasing decisions on e-commerce Shopee.

3. Quality information is positive and significant effect on the interest Buy Customer Shopee. These results demonstrate the good quality of the information that can foster customer buying interest shopee

4. Quality information and significant positive effect on customer purchasing decisions Shopee. These results demonstrate the good quality of the information that customers can decide to make a purchase

5. Buying interest and a significant positive effect on customer purchasing decisions Shopee. These results indicate increased buying interest resulted in a purchase decision

\section{Suggestions}

Based on the analysis, discussion and conclusions that have been raised in this study, it can be recommended:

1. Variable indicator of trust established by Concern, Reliability seller, and Credibility. Able to generate buying interest but has not been able to make purchasing decisions on the ECommerce Shopee. This means that with increasing confidence and not necessarily the customer decides not to shop online in the E-Commerce Shopee.

2. Shopee should always update the information either on the website or application related to the availability of goods and products in E-Commerce Shopee. With good quality information that will lead to customer buying interest and decided to transact online in Shopee

3. Buying interest raises the purchasing decision, Shopee customers will make purchases online when they feel confident and supported by good information from E-commerce Shopee. Parties are expected to mempetahankan Shopee customer trust and work to improve exceeding customer expectations.

4. For further Researchers will examine a similar theme, is expected to look more closely at other variables out of the study.

\section{Reference}

Abdulrahman, the US, and Muhammad, FG (2017). An Assessment of Awareness and Preference for Online Shopping: The Case of Undergraduate Students of Ibrahim Badamasi Babangida University Lapai, Niger State, Nigeria. Nigerian Chapter of Arabian Journal of Business and Management Review, 4 (3), 1-10. https://doi.org/10.12816/0037774

Alhasanah, JU, and Al, E. (2014). Influence Uses, Interactions and Quality Information Quality Web Services E-Commerce Purchasing kepurusan Against Online (Survey on Consumer www.get. Journal of Business Administration, 15 (2), 1-10. 
International Journal of Economics, Business and Accounting Research (IJEBAR)

Peer Reviewed - International Journal

Vol-4, Issue-1, 2020 (IJEBAR)

E-ISSN: 2614-1280 P-ISSN 2622-4771

https://jurnal.stie-aas.ac.id/index.php/IJEBAR

Hair, JF 2009. Multivariate Data Analysis. Edition 9. New Jersey: Pearson Education.

Kotler, Philip and Gary Armstrong. 2018. Principles of Marketing. Issue 15 Global Edition. Pearson.

Kotler, Philip and Kevin Lane Keller, 2016. Marketing Managemet. Issue 15 Global Edition. Pearson

Loo, R. (2006). Factors Affecting Satisfaction, Trust, and Loyalty Consumer Products Buying Online Website Kaskus. 1-7.

Majid, N. (2014). Analysis of Effect of Electronic Word of Mouth on Brand Image and Its Impact on Interest Buy Smartphone Samsung in Malang. Journal of Chemical Information and Modeling, 53 (9), 1689-1699.

Pavlou, PA, and Gefen, D. (2002). Building an Effective Online Marketplaces with Institutionbased trust, Proceedings of the Twenty-Third International Conference on Information Systems, 667-675.

Penia, A., \& Madiawati, Putu Nina. (2016). The Efect Of Trust And Information Quality To Online Purchase Decision On Site www.traveloka.com, E-Proceedings of Management:, 3 (2), 1880-1887.

Schiffman, LG, \& Kanuk, LL (2010). Consumer Behavior (10th ed). New Jersey, Pearson Prentice thing.

Sugiyono. (2013). Quantitative Research Methods, Qualitative and R \& D. Bandung: Alfabeta. 